\title{
Efficacy of Seed Priming on Yield and Yield Attributing Characters in French Bean (Phaseolus Vulgaris L.)
}

\author{
Preetilagna Dhal ${ }^{1}$, Gouri Shankar Sahu ${ }^{1}$ Arabinda Dhal ${ }^{2} *$ and Sunil Kumar Dash ${ }^{1}$ \\ ${ }^{1}$ Department of Vegetable Science, Odisha University of Agriculture and Technology, \\ Bhubaneswar-751003 (Odisha), India \\ ${ }^{2}$ Department of Plant Pathology, Odisha University of Agriculture and Technology, \\ Bhubaneswar-751003 (Odisha), India \\ *Corresponding author
}

\begin{abstract}
A B S T R A C T
An experiment entitled "Effect of priming on seed characters, disease incidence \& yield in French bean (Phaseolus vulgaris L.)" was conducted during Rabi 2018-19 in the Vegetable Research field, Department of Vegetable Science, College of Agriculture, Odisha University of Agriculture and Technology, Bhubaneswar. The trial was conducted

Keywords

Priming, yield, pod, French bean

Article Info

Accepted:

08 January 2020

Available Online:

10 February 2020

in Randomized Block Design with three replications and ten treatments. The treatments were $\mathrm{T}_{1}$ (Hydro priming), $\mathrm{T}_{2}\left(\mathrm{GA}_{3} 50 \mathrm{ppm}\right), \mathrm{T}_{3}(\mathrm{KCl} 2 \%), \mathrm{T}_{4}$ (Sodium Molybdate $500 \mathrm{ppm}$ ) $, \mathrm{T}_{5}($ Vitavax $2 \mathrm{~g} / \mathrm{kg}), \mathrm{T}_{6}$ (Pseudomonas fluorescens $\left.10 \%\right), \mathrm{T}_{7}$ (Trichoderma viride $\left.10 \%\right), \mathrm{T}_{8}$ $\left(\mathrm{GA}_{3} 50 \mathrm{ppm}+\right.$ T.viride 10\%), $\mathrm{T}_{9}$ (Sodium Molybdate $500 \mathrm{ppm}+$ Pseudomonas fluorescens $10 \%), \mathrm{T}_{10}$ (Control). The seeds of French bean variety Harsha were taken and different priming treatments were done in the laboratory followed by growing the crop in the field as per recommended package of practices. . The number of pods per plant was highest in $\mathrm{T}_{3}$ (32.40) and lowest in $\mathrm{T}_{10}(20.2)$ whereas the length of pod was highest in $\mathrm{T}_{2}$ (13.7) and was lowest in $\mathrm{T}_{10}(11.9)$. Number of seeds per pod was highest in $\mathrm{T}_{3}(5.44)$ followed by $T_{8} \& T_{2}(5.2), T_{5} \& T_{9}(5.1)$ but was the lowest in $T_{10} \& T_{4}$ (4.80). Average weight of fresh pod was significantly lowest in $\mathrm{T}_{4}, \mathrm{~T}_{6} \& \mathrm{~T}_{10}(5.3 \mathrm{~g})$ than the highest in $\mathrm{T}_{3}(6.5 \mathrm{~g})$ and all other treatments were intermediate and at par. From the present experiment it can be concluded that if $\mathrm{KCl} @ 2 \%$ is used for priming of French bean seeds it produces better yield attributing character \& also recorded the better yield of $13.28 \mathrm{t} / \mathrm{ha}$ followed by $12.19 \mathrm{t} / \mathrm{ha}$ with $\left(\mathrm{GA}_{3} 50 \mathrm{ppm}+T\right.$. viride $\left.10 \%\right)$ and the lowest pod yield of 8.10 t/ha was obtained in unprimed control.
\end{abstract}

\section{Introduction}

Seed is the integral factor in crop production. From the time immemorial seed quality is regarded as a cardinal element in the development of Agriculture and evidences of this has been observed in old Vedic literatures. In Manu Smriti it is mentioned that "Subeejam Sukshetre Jayate Sampadyathe" that means good seed in good soil yields abundantly. The requisite for good quality seed for increased production was 
identified as early as in the beginning of twentieth century. French bean (Phaseolus vulgaris L.) known as kidney bean/haricot bean/snap bean/navy bean/rajma bean/kidney bean/salad bean/string bean (Singh, 1999) is an important vegetable crop. French bean is divided into bush bean \& pole bean depending upon their growth habit. Bush bean has short stature with a height of around 20$60 \mathrm{~cm}$ tall whereas, pole type is trailing in nature.

A mean temperature of $20-25^{\circ} \mathrm{C}$ is required for its growth \& high pod yield. In French bean seeds do not germinate when temperature goes below $15^{\circ} \mathrm{C}$. In high summer \&hot weather blossom drop takes places. French bean requires well drained sandy loam soil, rich in organic matter for its proper growth \& development.

It can be grown in alluvial friable soil. It cannot withstand high alkaline, acidic or saline soils. Heavy clay soil ultimately hampers the growth of the seedlings \& leads to uneven \& poor crop stand.

Availability of quality seeds of improved cultivar is considered crucial for realizing productivity \& adoption of cultivars to different agro-climatic zones .Quality of seeds alone increase $10-15 \%$ more productivity .Lack of quality seeds continues to be one of the greatest impediments to bridge the vast yield gap. Therefore, to approach the potentially realizable yield of a cultivar, production \& distribution of quality seed is essential.

Seed priming is a modern technique of quality enhancement which is often used as seed invigoration treatment for rapid, uniform as well as to improve germination of seeds as well as optimum plant stand in field. Priming of seeds ultimately creates vigor in low vigor lots. Hence it appears to reverse the detrimental effects of seed deterioration (Srinivasan et al., 2009, Debbarma and Das, 2017) reported that seed priming is a presowing treatment which leads to a physiological state that enables seed to germinate more efficiently. Priming often involves soaking seed in predetermined amounts of water or limitation of the imbibitions time.

The beneficial as well as important role of seed priming is that it enhances the moisture content of seed \& increases $35-40 \%$ of its weight $\&$ ultimately activates the biochemical events, advancing seed germination process with radical emergence. The result of these changes leads to enabling completing of germination rapidly, leads to uniform crop stand \& synchronized flowering \& fruiting.

These physiological treatments induce tolerance to certain environmental stress (Vanangamudi et al.,2008).Various priming methods are used that is hydro-priming, osmo-priming, halo-priming, bio-priming, hormonal priming, as well as solid matrix priming are used in horticultural crops to increase speed \& uniformity of germination and improve field stand. Priming in pure water is called as hydro-priming .The most common techniques which are used for imbibitions of seeds are moistened blotters or soaking the seeds in water with or without aeration (Thornton and Powell, 1992).

\section{Materials and Methods}

The field experiment was carried out during Rabi season of the year 2018-19 in the Vegetable Demonstration plot of the Department of Vegetable Science, College of Agriculture, Orissa University of Agriculture and Technology, Bhubaneswar, Odisha. The French bean variety "Harsha" was taken during the course of investigation. The details of the materials used and methods employed 
are described in this chapter. The field experiment was conducted under irrigated condition during Rabi 2018-19 at the demonstration plot of the Department of Vegetable Science, College of Agriculture. OUAT, Bhubaneswar, which is situated at $22^{0}$ $15^{\prime}$ North latitude, $80^{\circ} 22^{\prime}$ East longitude and in an altitude of $25.5 \mathrm{~m}$ above the mean sea level (MSL) and $63 \mathrm{kms}$ from Bay of Bengal.

Soil of the experimental site was medium sandy loam soil. Before the initiation of the experiment the soil samples were collected and soil sample was analyzed for the physical and chemical characteristics. The land was thoroughly ploughed cross wise before 15 days of sowing to bring it to proper tilth. Weeds and other crop roots and pebbles were removed.

Then, the land was properly levelled with tractor driven leveller. The plots were laid out as per the layout plan with regular bonds and irrigation channels. The seed of French bean variety Harsha, was collected from Shriram fertilizer \& pesticide is a popular variety of Odisha \& was purchased from local seed dealer. The plant is bushy and It produces pod of $9-10 \mathrm{~cm}$ with a yield potential of $12-16$ tons per hectare.

In case of hydro priming the seeds were immersed inside water for about $5 \mathrm{hrs}$. Then the seeds were taken out as well as air dried followed by sowing in prepared field. In case of $\mathrm{GA}_{3} 50 \mathrm{ppm}, \mathrm{KCl}(2 \%)$, Sodium molybdate (500 ppm), Vitavax (2g /1lit), Pseudomonas fluroscens (10\%), Trichoderma viride (10\%), $\left(\mathrm{GA}_{3} 50 \mathrm{ppm}+\right.$ Trichoderma viride 10\%), (Sodium molybdate 500 ppm+ Pseudomonas fluroscens 10\%) solution was prepared and the same procedure was followed for treatment of the seeds.

The total number of pods per plant after plucking from ten selected tagged plants at different harvest was counted and average was recorded as number of pods per plant.

The length of ten pods randomly selected from tagged plants from each plot of each replication were measured and expressed in centimeter from the attachment end to the tip using a meter scale and the mean value was calculated as fruit length and expressed in centimeter.

Well-developed pods were collected and shelled to count, the number of seed per pod after dividing the total number of seeds by the total number of pods. Ten pods harvested from tagged plants were weighed and was divided by the number of pods to get the average fresh weight of pod.

The weight of fruits from ten numbers of tagged plants from each plot was summed up and the average was computed in order to get the final fruit yield per plant (g). The weight of fruits from tagged and non-tagged plants from each plot was collected and was computed in order to get the pod yield per plot $(\mathrm{kg})$. The total fruit yield per plot was converted to total fruit yield in $(\mathrm{q} / \mathrm{ha}$ ) for each replications to obtain yield /ha.

\section{Statistical analysis}

Analysis of variance (ANOVA) was carried out on mean values separately for each character adopting standard analysis of variance technique for RBD design (Panse and Sukhatme, 1985). The analysis of variance for each of the character was carried out with the mean value of data collected from sample plants from each plot and the mean average data were used for the total variance into components due to replication, treatment and error. The " $F$ " test was done for testing the significance of the findings. Approximate standard error for each factor was worked out to compare the treatment 
means and the critical difference (CD) was calculated at 5\% level of significance using the following formula.

\section{Results and Discussion}

\section{Influence on the numbers of pods per plant}

The data on number of pods per plant is presented in Table 1 . The number of pods per plant is an important yield attributing character. It was observed that due to different priming treatment there were significant differences in number of pods per plant. The highest number of pods per plant was found with $\mathrm{T}_{3}$ (32.40) followed by $\mathrm{T}_{2}$ (30.4) and 28.5 in $T_{5}$. Treatment $T_{8}$ recorded pod number of 28.3 per plant and it was 27.5 in $\mathrm{T}_{7}, 26.5$ in $\mathrm{T}_{1} \& 26.2$ in $\mathrm{T}_{6}$. The lowest pod number of 20.2 was observed with $\mathrm{T}_{10}$.

However the highest pods per plant (32.40) recorded in $\mathrm{KCl} 2 \%$ was statistically at par with $\mathrm{GA}_{3}(50 \mathrm{ppm})$ recording 30.4. Significant variations of number of pods were recorded with different priming treatments and 32.40 being the highest in $T_{3}$ closely followed by $T_{2}$
(30.4) and they are statistically at par. However the control plot recorded the lowest number pod that is 20.2. The number of pods per plant was 3.03 to 21.21 per cent increased over control. The highest (21.21) per cent increase was recorded in the treatment where seeds priming was done with $2 \% \mathrm{KCl}$ followed by $\mathrm{GA}_{3}(50 \mathrm{ppm})+$ T.viride $(10 \%)$ treated seed (Fig 1).

Shairat madari et al (2017) reported application of gibberlic acid improved the growth and physiological traits under field condition which supports the present findings. The findings also supported by the results of Golezani et al., (2010) \& Mazed et al., (2015).

\section{Influence on the pod length}

The length of pod due to various treatments did not varied significantly in different treatments. The length of pod varied from $11.9 \mathrm{~cm}$ in control to $13.8 \mathrm{~cm}$ in $\mathrm{T}_{8}$ (Table 1 ). The length of pod varied in a range of 11.9 $\mathrm{cm}$ in control to highest $13.8 \mathrm{~cm}$ in $\mathrm{GA}_{3}$ and T.viride combination priming.

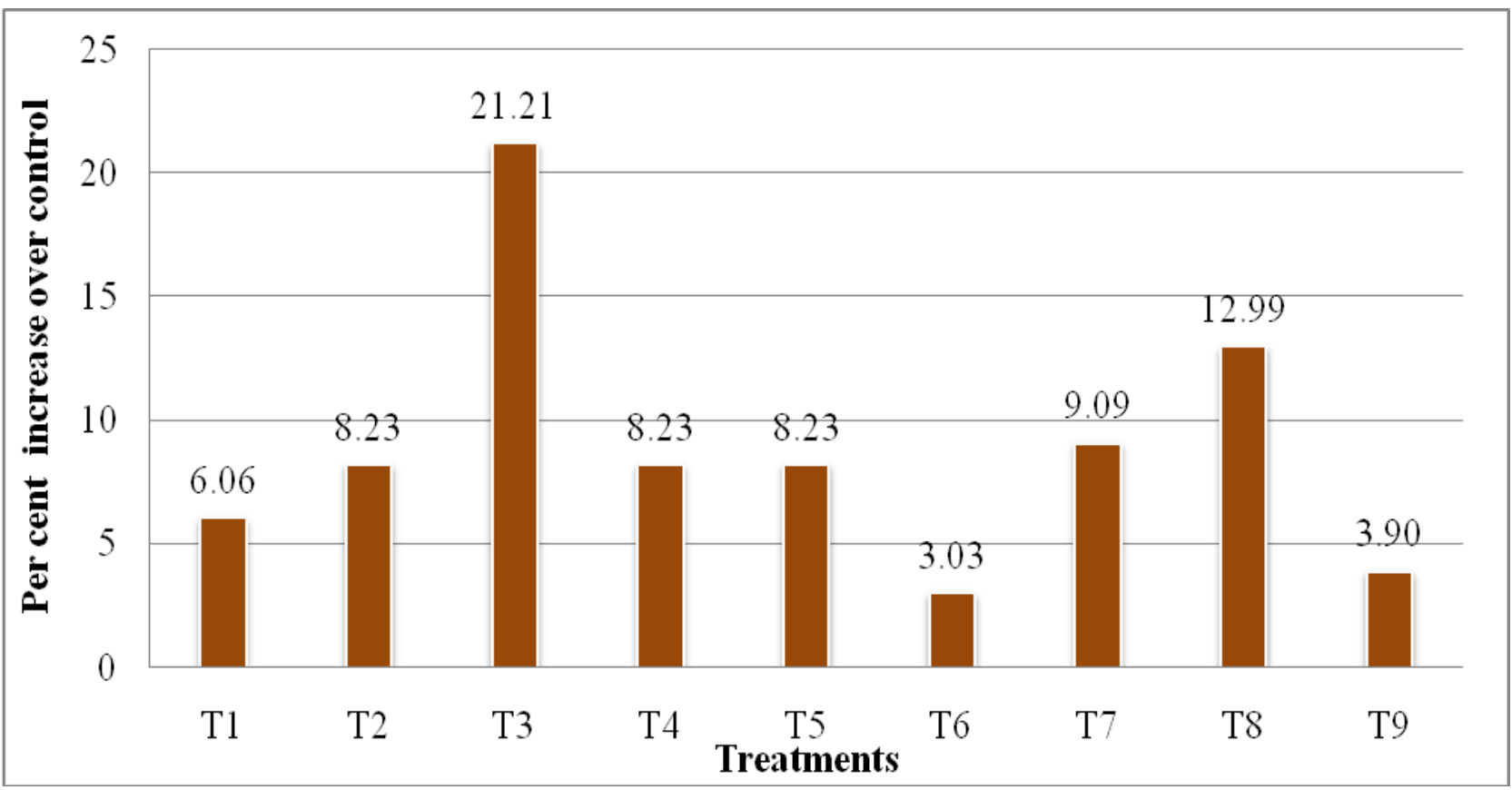

Fig.1 Influence of priming on the percentage increase of number of pods 
The highest (15.97) per cent increase was recorded in the treatment where seeds priming was done with $\mathrm{GA}_{3}(50 \mathrm{ppm})+$ T.viride $(10 \%)$ followed by $\mathrm{GA}_{3}(50 \mathrm{ppm})$ treated seed (Fig 2).However, there is no significant variation among all the treatments which expressed seed priming has no impaction on length of pods in the present investigation. These findings in close agreement with results of Mazed et al., (2015).

\section{Influence on the number of seeds per pod}

The data on average number of seeds per pod is given in Table 1 . The average number of seeds per pod varied from 4.80 to 5.44 per pod. It was observed that there was no significant variation in number of seeds per pod among the treatments. The highest numbers of seeds per pod 5.44 was recorded with $\mathrm{T}_{3}$ followed by 5.2 in $\mathrm{T}_{2}$ and $\mathrm{T}_{8}$ and 5.1 in $\mathrm{T}_{5} \& \mathrm{~T}_{9}$.

The lowest number of seeds per pod of 4.80 was found with $T_{10} \&_{4} T_{4}$ The recorded observations reflected no significant variations among the treatments with respect to number of seeds per pod. However the average number of pods varied in a range 4.8 to 5.44 among the treatments.

\section{Influence on the fresh weight of pod}

The average weight of fresh pod as found during the experiment is presented in Table 4.6. The highest pod weight of $6.5 \mathrm{~g}$ was recorded in $\mathrm{T}_{3}$ followed by $6.3 \mathrm{~g}$ in $\mathrm{T}_{8}$ and $6.2 \mathrm{~g}$ in $\mathrm{T}_{7}$. The lowest average fresh weight of $5.3 \mathrm{~g}$ was recorded in $\mathrm{T}_{4}, \mathrm{~T}_{6}$ and $\mathrm{T}_{10}$.Other treatments like $\mathrm{T}_{2}(6.00 \mathrm{~g}), \mathrm{T}_{5}(5.8 \mathrm{~g}), \mathrm{T}_{1}(5.7 \mathrm{~g})$ $\mathrm{T}_{9}(5.4 \mathrm{~g})$, recorded intermediate values for weight of fresh pod.

However, highest fresh weight of pod was recorded in $(\mathrm{KCl} 2 \%)$ treatment which was found statistically at par with other treatments. The priming with $\mathrm{KCl}(2 \%)$ recorded the highest fresh weight of pod that is 6.5 which was at par with all other priming treatments besides control, Sodium molybdate and $P$. fluroscens and those three recorded the lowest $5.3 \mathrm{~g}$ of fresh weight of pod.

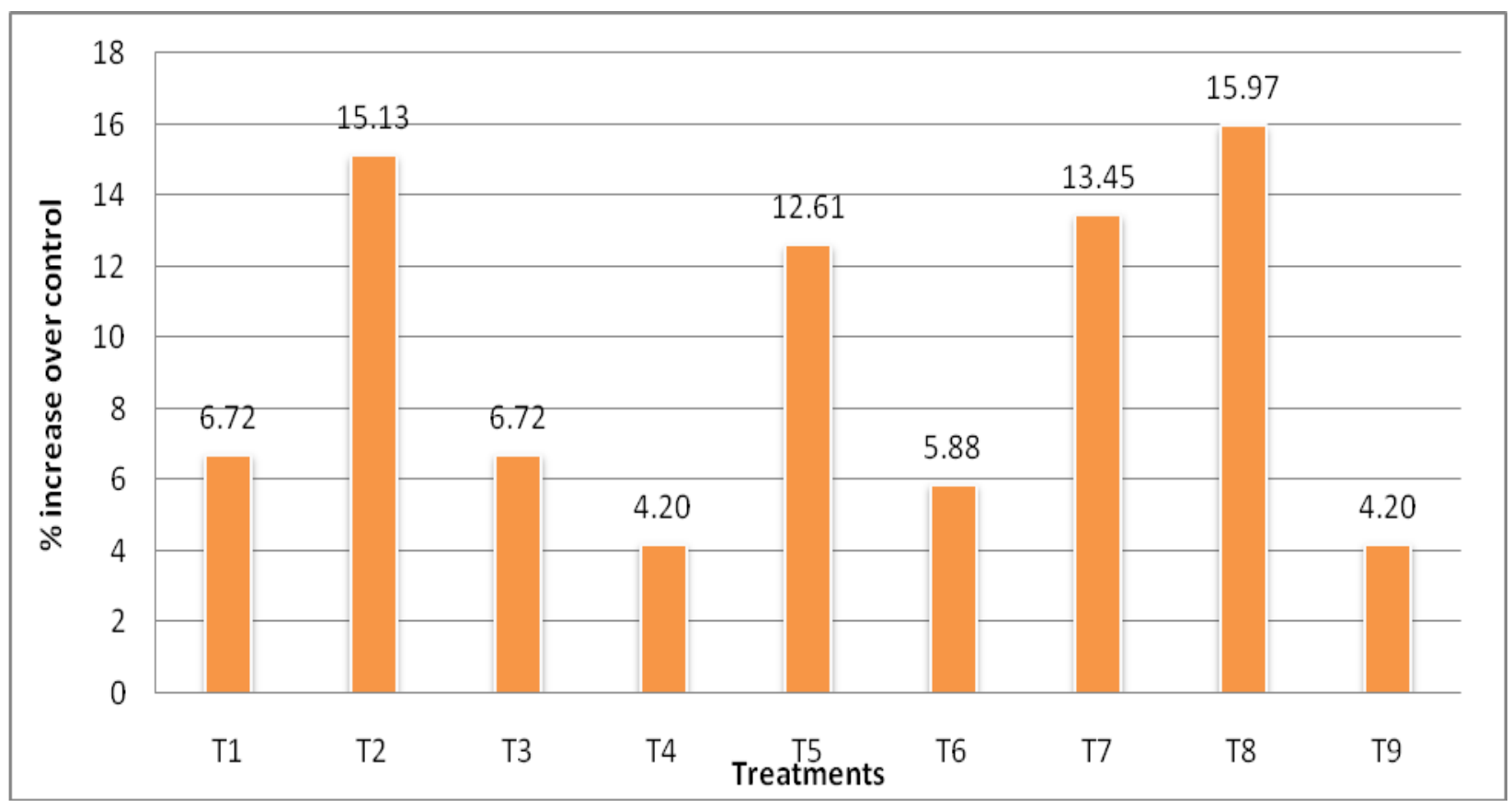

Fig.2 Influence of priming on the percentage increase of pod length 
Table.1 Influence of seed priming on pod characteristics

\begin{tabular}{|c|c|c|c|c|c|}
\hline & Treatments & $\begin{array}{l}\text { Number of } \\
\text { pods per plant }\end{array}$ & $\begin{array}{l}\text { Length of pod } \\
\text { (cm) }\end{array}$ & $\begin{array}{l}\text { Number of } \\
\text { seeds per pod }\end{array}$ & $\begin{array}{l}\text { Fresh weight } \\
\text { of one pod (g) }\end{array}$ \\
\hline T1 & Hydropriming & 26.5 & 12.7 & 4.9 & 5.7 \\
\hline T2 & $\mathrm{GA}_{3}(50 \mathrm{ppm})$ & 30.4 & 13.7 & 5.2 & 6.0 \\
\hline T3 & $\mathrm{KCl}(2 \%)$ & 32.40 & 12.7 & 5.44 & 6.5 \\
\hline T4 & Sodium Molybdate500 ppm & 25.5 & 12.4 & 4.8 & 5.3 \\
\hline T5 & $\operatorname{Vitavax}(2 \mathrm{~g} / \mathrm{kg})$ & 28.5 & 13.4 & 5.1 & 5.8 \\
\hline T6 & P.fluorescens(10\%) & 26.2 & 12.6 & 4.9 & 5.3 \\
\hline T7 & T.viride $(10 \%)$ & 27.5 & 13.5 & 5.0 & 6.2 \\
\hline T8 & $\mathrm{GA}_{3}(50 \mathrm{ppm})+$ T.viride $(10 \%)$ & 28.3 & 13.8 & 5.2 & 6.3 \\
\hline T9 & $\begin{array}{lrrr}\text { Sodium Molybdate } & 500 & \mathrm{ppm} \\
+ \text { P.fluorescens }(10 \%) & & \end{array}$ & 24.6 & 12.4 & 5.1 & 5.4 \\
\hline \multirow[t]{3}{*}{ T10 } & Control & 20.2 & 11.9 & 4.8 & 5.7 \\
\hline & $\mathrm{SE}(\mathrm{m}) \pm$ & 1.24 & 0.95 & 0.42 & 0.37 \\
\hline & CD5\% & 3.77 & 2.89 & 1.29 & 1.13 \\
\hline
\end{tabular}

\section{Influence on the pod yield}

The fresh pod yield per hectare in the experiment is presented in Fig 3 where it was found that due to various priming treatments \& their combinations there was significant difference in yield. It was observed that treatments like $\mathrm{T}_{6}(9.13 \mathrm{t} / \mathrm{ha}), \mathrm{T}_{9}(9.14 \mathrm{t} / \mathrm{ha}), \mathrm{T}_{4}$ $(9.51 \mathrm{t} / \mathrm{ha})$ and $\mathrm{T}_{1}(9.77 \mathrm{t} / \mathrm{ha})$ produced significantly less yield as compared to treatments like $\mathrm{T}_{3}$ (13.28ton), $\mathrm{T}_{8}$ (12.19 ton) and $\mathrm{T}_{2}$ (11.86ton)

The highest pod yield of 13.28t/ha was obtained in $\mathrm{T}_{3}$, followed by $12.19 \mathrm{t} / \mathrm{ha}$ in $\mathrm{T}_{8}$ and $11.86 \mathrm{t} / \mathrm{ha}$ in $\mathrm{T}_{2}$ which is at par. The lowest pod yield of $8.10 \mathrm{t} / \mathrm{ha}$ was observed in $\mathrm{T}_{10}$. The treatments like $\mathrm{T}_{5}(10.49 \mathrm{t} / \mathrm{ha}), \mathrm{T}_{7}$ (10.88 t/ha), $\mathrm{T}_{2}(11.86 \mathrm{t} / \mathrm{ha})$ and $\mathrm{T}_{8}(12.19 \mathrm{t} / \mathrm{ha})$ recorded intermediate pod yield per hectare during the investigation. The observation recorded on pod yield per hectare revealed the highest yield of 13.28 ton/ha in $\mathrm{T}_{3}$ closely followed by $12.19 \mathrm{t} / \mathrm{ha}$ in $\mathrm{T}_{8}$ and $11.86 \mathrm{t} / \mathrm{ha}$ in $\mathrm{T}_{2}$ and they are statistically at par. The yield recorded was the least in unprimed control plot $(8.10 \mathrm{t} / \mathrm{ha})$.

The pod yield was positively correlated with number of pods per plant (Fig-4). Maiti et al., (2013) recorded higher yield in vegetable seeds due to priming and Toklu et al., (2016) reported that $\mathrm{PEG}, \mathrm{KCl}$ and hydro priming helped increase in yield in wheat which supports the present findings .

Yadav et al., (2013) reported that the bioagent Trichoderma showed better result in yield and yield attributing parameters compared to other bio inoculants which supports the present findings. Monalisa et al (2017) reported the increased pod yield in primed seeds when compared to control while experimenting on pumpkin seeds. 


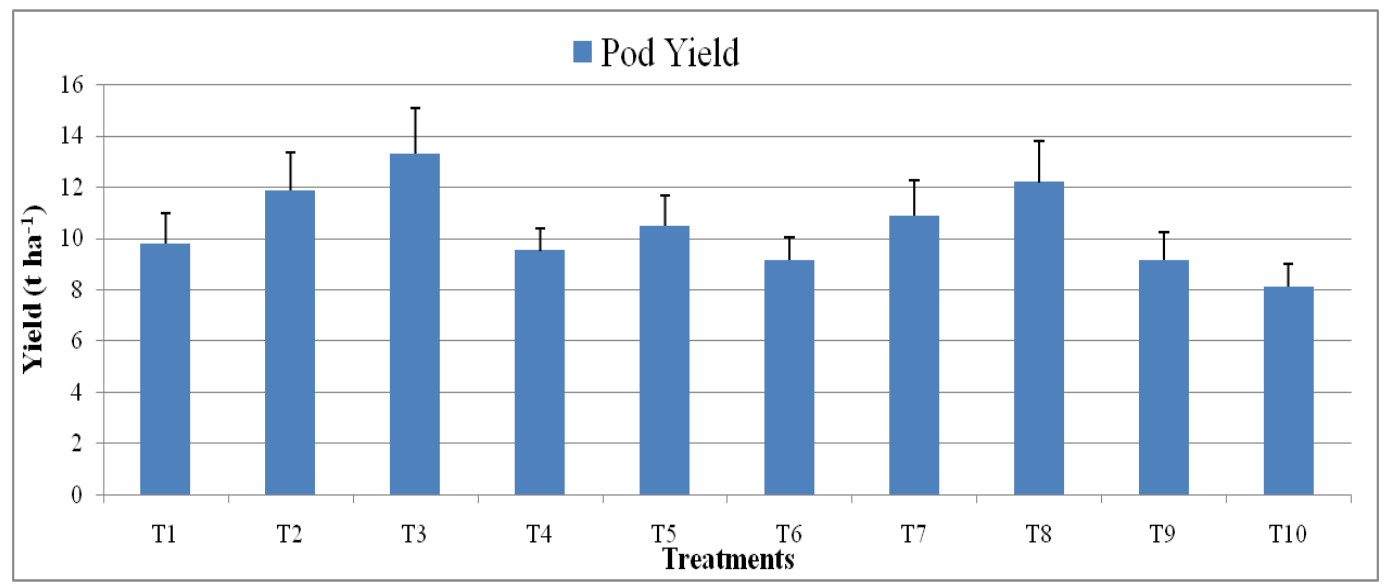

Fig.3 Influence of priming on pod yield

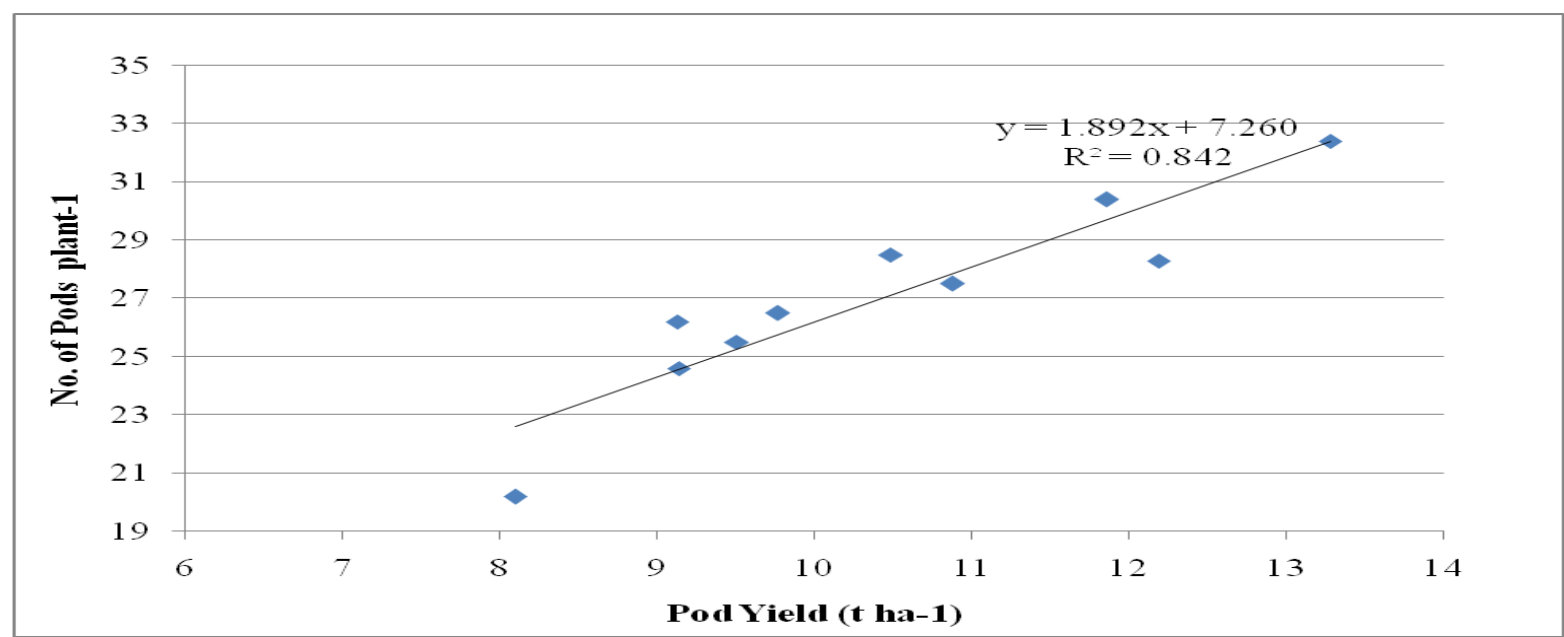

Fig.4 Relationship between pod yield and no. of pods per plant

The number of pods per plant was maximum in $T_{3}(32.40)$ and $T_{2}(30.4)$ which were at par and minimum in $\mathrm{T}_{10}(20.2)$ whereas the length of pod was maximum in $\mathrm{T}_{2}$ (13.7) and was minimum in $\mathrm{T}_{10}$ (11.9). Number of seeds per pod was highest in $\mathrm{T}_{3}(5.44)$ followed by $\mathrm{T}_{8} \&$ $\mathrm{T}_{2}$ (5.2), $\mathrm{T}_{5} \& \mathrm{~T}_{9}$ (5.1) but was the lowest in $\mathrm{T}_{10} \& \mathrm{~T}_{4}(4.80)$.

Average weight of fresh pod was significantly lowest in $\mathrm{T}_{4}, \mathrm{~T}_{6} \& \mathrm{~T}_{10}(5.3 \mathrm{~g})$ than the highest in $\mathrm{T}_{3}(6.5 \mathrm{~g})$ and all other treatments were intermediate and at par. The most economic character i.e. total yield per plot was highest with $\mathrm{T}_{3}(11.96 \mathrm{~kg})$ followed by $10.98 \mathrm{~kg}$ in $\mathrm{T}_{8}$ and $10.68 \mathrm{~kg}$ in $\mathrm{T}_{2}$ and was lowest in $\mathrm{T}_{10}(6.57$ $\mathrm{kg}$ ). The pod yield per hectare was maximum in $\mathrm{T}_{3}(13.28 \mathrm{t} / \mathrm{ha})$ followed by $(12.19 \mathrm{t} / \mathrm{ha})$ in $\mathrm{T}_{8}$. But it was lowest in $\mathrm{T}_{10}$ i.e. $(8.10 \mathrm{t}) / \mathrm{ha}$.

\section{References}

Debabrama M and Das P. (2017). Priming of Seed: Enhancing Growth and Development.Int.J.Curr.Microbiol.App. Sci 6(12): 2390-2396

Golezani KG , Jafari SF and Kolvanagh J S.2010. Seed Priming and Field Performance of Soybean (Glycine max L.) in Response to Water Limitation. Notule Botanicae Horti Agrobotanical ,39(2):186-189 .

Maiti R,Rajkumar D, Jagan M, Parmanik K and Vidyasagar P.2012 . Effect of Seed 
Priming on Seedling Vigour and Yield of Tomato and Chilli. International Journal of Bio-resource and Stress Management 2013, 4(2):119-125.

Mazed HEM, Haque $\mathrm{N}$ and Abdullah $\mathrm{Md}$. 2015. Effect of seed priming on growth, yield and seed quality of chickpea .International Journal of Multidisciplinary Research and Development , 2 (7) :142-147.

Monalisa SP, Beura J K , Tarai RK and Naik M. 2017. Seed quality enhancement through biopriming in common bean (Phaseolus vulgaris. L). Journal of Applied and Natural Science, 9(3):1740-1743.

Shairatmadari M.H, Parsa M, Nezami A and Kafi M.2017. Effect of hormonal priming with gibberlic acid on emergence, growth \& yield of chickpea under drought stress. Bioscience Research 14(1):34-41.

Sharma A D, Rathoreb SVS , K Srinivasan and Tya-gia RK. 2014. Comparison of various seed priming methods for seed germination, seedling vigour and fruit yield in okra (Abelmoschus esculentus L.Moench).

Scientia Horticulturae.165:75-81.

Singh SP. (1999). Improvement of smallseeded race Mesoamerica cultivars. In: Sing, S.P. ed. Common bean improvement in the twenty-first century. Kluwer Achademic Publishers.
Dordrecht, Boston, London. pp.255274.

Srinivasan K,Jain SK, Saxena S, Radhamani J and Uprety R. 2009. Seed priming and fortification. Seed Research Journal, 37:10-12.

Thirnton MJ and Powell AA. (1992). Shortterm aerated hydration for the improvement of seed quality in Brassica oleracea. Seed science Research, 2:41-49.

Toklu F.2015. Effects of Different Priming Treatments on Seed Germination Properties, yield components \& grain yield of lentil (Lens culinaris Medik.) .Not Bot Horti Agrobo, 43(1):153-158.

Vanangamudi, K., Bhaskaran, M., Bharati, A. and Maregesan P. (2008). Seed hardening for drought resistance. Advances in seed science and technology 1: 195-200.

Vazirimehr MR , Ganjali HR, Rigi K , Keshtehgar A. 2014. Effect of seed priming on quantitative traits on corn. Int. J Pl Sci.4:134-140.

Yadav SK, Dave A, Sarkar A, Harikesh BS and Sarma BK. 2013. Co-inoculated biopriming with Trichoderma, Pseudomonas and Rhizobium improves crop growth in Cicer arietinum and Phaseolus vulgaris. International Journal of Agriculture, Environments and Biotechnology 6(2):255-259.

\section{How to cite this article:}

Preetilagna Dhal, Gouri Shankar Sahu Arabinda Dhal and Sunil Kumar Dash. 2020. Efficacy of Seed Priming on Yield and Yield Attributing Characters in French Bean (Phaseolus Vulgaris L.). Int.J.Curr.Microbiol.App.Sci. 9(02): 915-922. doi: https://doi.org/10.20546/ijcmas.2020.902.108 